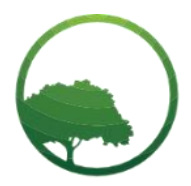

Research in Business \& Social Science

IJRBS VOL 11 NO 1 (2022) ISSN: 2147-4478

Business \& Social Science IJRBS

\title{
Legal and regulatory framework of long term sustainability of outer space activities (LTSOSA), space security and its contribution towards human security
}

Ida Bagus Rahmadi Supancana

Crossref

Faculty of Law, Atma Jaya Catholic University, Jakarta, Indonesia

A R T I C L E I N F O
Article history:
Received 16 December 2021
Received in rev. form 07 Feb. 2022
Accepted 11 February 2022
Keywords:
Legal and Regulatory Framework,
Long Term Sustainability of Outer
Space Activities (LTSOSA), Space
Security, Contribution, Human
Security
JEL Classification:
O15, P36

\begin{abstract}
A B S T R A C T
Long Term Sustainability of Outer Space Activities (LTSOSA) was adopted during the UNCOPUOS Session in June 2019. It consists of 21 guidelines in four (4) categories, namely: policy and regulatory framework of outer space activities; safety of outer space operations; international cooperation, capacity building and awareness; and technical research and development. The LTSOSA is in line with the definition of Space Security which relates to guaranteed access to Space and the ability to freely exploit space for various purposes. Space Security cover both: safety, sustainability and the security of the space system and actors. While Human Security is an approach to assist Member States in identifying and addressing widespread and cross-cutting challenges to the survival, livelihood and dignity of their people. It call for people-centered, comprehensive, context-specific and preventionoriented responses that strengthen the protection and empowerment of all people.This article will be focused on analyzing and elaborating three (3) main issues: The correlation among LTSOSA, Space Security and Human Security; The Contributions of LTSOSA and Space Security toward the achievement of Human Security's Objectives; and Legal and Regulatory Framework of LTSOSA, Space Security and Human Security.
\end{abstract}

(C) 2022 by the authors. Licensee SSBFNET, Istanbul, Turkey. This article is an open access article distributed under the terms and conditions of the Creative Commons Attribution (CC BY) license (http://creativecommons.org/licenses/by/4.0/).

\section{Introduction}

The development and formulation of LTSOSA was initiated by the Scientific and Technical Sub-Committee of the United Nations Committee on the Peaceful Uses of Outer Space (UNCOPUOS). In 2110 it was developed based on prevailing best practices. In 2014 Session of Technical and Scientific Sub Committee of UNCOPUOS, 31 points of the draft Guidelines was presented and discussed. In 2016 the discussion on 12 Guidelines was finalized, followed by second set of 9 Guidelines was also finalized in 2018 . The 21 Guidelines was formally agreed and adopted by UNCOPUOS Plenary Session in 2019 (Yan, 2019).

As a concept LTSOSA is the ability to maintain the conduct of space activities indefinitely into the future in a manner that realizes the objective of equitable access to the benefits of the exploration and use of outer space for peaceful purposes, in order to meet the need of the present Generations while preserving the outer space for future Generation (Permatasari, 2019; Budisulistiorini et al, 2018).

The LTSOSA consist of 21 guidelines which comprise of a collection of internationally recognized measures for ensuring the LTSOSA and enhancing the safety of space operation. The Guidelines address the policy, regulatory, operational, safety, scientific, technical, international cooperation, and capacity building aspect of space activities. They are based on substantial body of knowledge, as well as experience of States, International Inter-Governmental Organizations and relevant national and international

\footnotetext{
* Corresponding author.

(C) 2022 by the authors. Hosting by SSBFNET. Peer review under responsibility of Center for Strategic Studies in Business and Finance.

https://doi.org/10.20525/ijrbs.v11i1.1671
}

Citation: Supancana, I. B. R., (2022). Legal and regulatory framework of long term sustainability of outer space activities (LTSOSA), space security and its contribution towards human security. International Journal of Research in Business \& Social Science (2147-4478), 11(1), 358-363 
non-governmental entities. The Guidelines also relevant to all space actors and space activities, whether planned or on-going, as practicable, and to all phases of a space mission, including launch, operation, and end-of life disposal (Nasution \& Zahra, 2017; Bejarano et al, 2019)

The purpose of the Guidelines is to assist States and Intergovernmental organization, both individually and collectively, to mitigate the risk associated with the conduct of outer space activities so that the present benefits can be sustained and future opportunities realized. Consequently, the implementation of the guidelines should promote international cooperation in the peaceful uses and exploration of outer space (Nastiti \& Giyarsih 2019; Akhir et al, 2016).

The method for collecting data and information for this article is based on desk study from available sources, both primary, secondary and tertiary legal materials. The analysis is applying qualitative and normative approaches, in particular on the relevant issues regarding LTSOSA, Space Security and how it contributes to the attainment of Human Security's objectives.

\section{Conceptual Background and Human Security}

The concept of Human Security was introduced in the UNDP's 1994 Human Development Report, entitled "New Dimension of Human Security". The Report introduced a new concept of Human Security, which equates security with people rather than territories, and with development rather than arms.

The 1994 Report stressed that Human Security is people-centered, and "is concerned with how people live and breath in society, how freely they exercise their many choices, how much access they have to market and social opportunities and whether they live in conflict or in peace". The concept revolves around the importance of affording people "freedom from fear" and "freedom from want".

UNGA Resolution no 66/290 of 2012 was an important milestone as it described Human Security as "the right of people to live in freedom and dignity, free from poverty and despair". In 2018 the UN Secretary General said that "Human Security, National Security and Global Security are indivisible. When people fear for their lives, their communities, societies and countries are at increased risk. When people enjoy safety, so do their countries and the World". Human Security links to human development approach which is about expanding the richness of human life, rather than simply the richness of the economy in which human being live are clear: one cannot exist without the other.

There are some initiatives relevant to Human Security, such as:

i. Global Initiative on Human Security: people's protection and empowerment.

ii. The Security System Reform Agenda: linking Security, Development and Governance.

iii. Initiatives led by Government and Other International Networks.

iv. Civil Society: a critical partner for the State to enhance Human Security.

There are some other relevant initiatives to Human Security: 2030 Agenda for Sustainable Development; The New York Declaration for Refugees and Migrants; The Sendai Framework Disaster Risk Reduction; The Sustaining Peace Agenda. As with human development approach, the concept of Human Security is closely related to the 2030 Agenda. Human Security's People-Centered approach is essential to realize the core ambition of the 2030 Agenda- that is to have no-one behind.

The concept of Human Security ensured a better Agenda 2030 than would otherwise have been possible to negotiate. Both the SDG and Human Security recognize that development challenges are complex and interlinked and that, an integrated, multidimensional approach to development is needed. The humanitarian development-peace nexus also sits at the core of the notion of Human Security. Essentially it is a recognition of the fact that sustainable development and sustaining peace are two side of the same coin.

The 2030 Agenda emphasizes a very basic human needs such as a world free from poverty, hunger, decease as well as access to safe drinking water and food. SDG no 16 is one of the key SDG's to promote Human Security. It sets us the goal to promote peaceful and inclusive societies for sustainable development, provide access to justice for all and build effective, accountable and inclusive institutions at all level.

\section{LTSOSA and Human Security}

One of the main concerns of LTSOSA is sustainability of outer space activities both for Present and Future Generations. Such sustainability cover both to space environment, safety and operations, international cooperation, capacity building as well as scientific and technical research.

Human Security puts it emphasize over people security which are free from fear, free from want, free from poverty and free from despair. LTSOSA through the application of space science and technology and its application would be able to support the achievement of Human Security's Goal and Sustainability Development Goals.

\section{Space Security and Human Security}

As Space Security developed from its conservative concepts of security to its expanding concepts covering safety, sustainability and security of space system and actors, it is in line with the developing concept of Human Security, from narrow and conservative 
meaning of security to expand from territorial security to people security and from arms to development. The expansion of the concept of security, both Space Security as well as Human Security would enable that space security can also be dedicated to the achievement of Human Security.

\section{Human Security and SDG}

As with human development approach, the concept of Human Security is closely related to SDG's 2030 Agenda. Human Security's people-centered approach is essential tools to realize the core ambition of SDG's 2030 Agenda- that is to Leave No-One Behind. Both SDG's 2030 and Human Security recognize that development challenges are complex and interlink and that, an integrated, multidimensional approach to development is needed.

\section{Contribution of LTSOSA and Space Security to the Attainment of Human Security's Objectives}

Space Contribution to SDG and Human Security

i. Contribution to SDG no 4 on Quality Education: provide precious hands-on opportunities for students in university;

ii. Contribution to SDG 9 on Industry, Innovation and Infrastructure: offer opportunity for Developing Countries to develop space technology domestically and build basic elements for a potential space industry and inspire innovations in the country;

iii. Contribution to SDG no 10 on Reducing Inequalities: reduce the "space gap" be tween space-faring nation. Countries benefitting the program become space-faring countries;

iv. Contribution to SDG no 16 on Peace, Justice and Strong Institutions: Cooperation in outer space is of great importance for world peace. Ensure the compliance of international space law and play an important role in supporting new-space-faring nations to develop national space law;

v. Contribution to SDG no 17 on Partnership for The Goal: triangular cooperation (Japan- Kenya-Italy-UNOOSA), SouthSouth Cooperation, Technology transfer.

\section{LTSOSA, Space Security and its contribution to Human security}

The Objective of Human Security: to create political, economic, social, cultural and environmental conditions in which people live knowing that their vital rights and freedom are secure; to keep critical pervasive threats from invading the vital core of human lives. Another version of Human Security's Objectives is formulated as "To Safeguard of the Vital Core of All Human Lives from Critical and Pervasive Threat, in a way that is consistent with-long term Human Fulfillment". On the interpretation on some keywords on such definitions are as follows: Safeguard means human security is deliberately protective; Vital Core means human security is contained in scope; All Human Lives means human security is "people-centered"; Critical and Pervasive Threat means the focus of human security is squarely on human lives; and Human Fulfillment means human security focuses on a limited core of individual activities and abilities, on a minimal subset of human development and human rights. LTSOSA through the implementation of its 21 Guidelines and Space Security through its range of activities may potentially be contributed to the achievement of Human Security's Objectives.

\section{Legal and Regulatory Framework to Support the Contribution of LTSOSA and Space Security to Human Security}

Legal and Regulatory Framework of LTSOSA

i. Guidelines for the LTSOSA as adopted by the Plenary Meeting of the UNCOPUOS in June, 2019.

ii. This Guidelines touch on a range of activities aimed at enhancing sustainability of space environment, safety of space operations, international cooperation, capacity building, and scientific and technical research.

iii. It is voluntary, but the Guidelines do become legally binding as States adopt the recommended measures through national legislation and regulation.

iv. The Guidelines represent the most significant international agreement to advance the governance of State Security in decades.

v. The Guidelines make a critical link between the three (3) pillars of Space Security: safety, sustainability, and the security of space systems and actors.

Legal and Regulatory Framework of Space Security

i. UNGA Resolution no 75/36 on Reducing Space Threats through Norms, Rules and Principles of Responsible Behaviors. By UNGA Resolution 75/36, the General Assembly encouraged Member States to study existing and potential threats and security risks to space system, including those arising from actions, activities or systems in outer space or on Earth, characterize actions and activities that could be considered responsible, irresponsible, or threatening and their potential impact on international security, and share their ideas on the further development and implementation of norms, rules and 
principles of responsible behaviours and on the reduction of the risks and misunderstanding and miscalculations with respect to outer space.

ii. Draft International Code of Conduct for Outer Space Activities of 2014:This draft in the form of proposed Soft Laws contain some provisions on Space Security, covering: purpose and scope; general principles; promotion with and promotion of Treaties, Conventions and other commitment relating to outer space activities; measures on outer space operation and space debris mitigation; notification of outer space activities; information of outer space activities; consultation mechanism; meeting of subscribing States; central point of contact; and participation by regional integration organization and international intergovernmental organization.

iii. Prevention of Arms Race in Outer Space (PAROS):

PAROS divided into two (2) parts: Part I on Military Space Activities and Their Legal Limitation; Part II on Prevention of Arms Race in Outer Space. Part I consist of Chapter 1 on the need for security in outer space covering issues related to the prevention of arms race in outer space and linkages between bilateral USSR/US initiatives and multilateral initiatives. Part II cover some international agreements containing provisions applicable to arms limitation and prohibition in outer space and general provisions concerning activities in outer space.

UNGA Resolution on General and Complete Disarmament: Transparency and Confidence Building Measures in Outer Space Activities:

This resolution reaffirms the right of all countries to explore and use of outer space in accordance with International Law. It also reaffirms that preventing an arms race in outer space is in the interest of maintaining international peace and security and is a essential condition for the promotion and strengthening international cooperation in the exploration and use of outer space for peaceful purposes. It encourages Member States to continue to review and implement, to the greatest extent practicable, the proposes transparency and confidence building measures through the relevant national mechanism, on a voluntary basis and in a manner consistent with the national interests of Member States.

\section{Legal and Regulatory framework of Human Security}

UNGA Resolution no 66/290 of 2012 on Follow-Up to Paragraph 143 on Human Security of the 2005 World Summit Outcome:

The Resolution recognize that development, human rights and peace and security, which are the three pillars of the United Nations, are interlink and mutually reinforcing. It agreed on the common understanding that the notion of human security includes the following:

i. The right of people to live in freedom and dignity, free from poverty and despair;

ii. Human security call for people-centered, comprehensive, context-specific and prevention-oriented responses that strengthen the protection and empowerment of all people and all communities;

iii. Human security recognizes the interlinkages between peace, development and human rights, and equally considers civil, political, economic, social and cultural rights;

iv. The notion of human security is distinct from the responsibility to protect and its implementation;

v. Human security does not entail the threat or the use of force or coercive measures;

vi. Human security is based on national ownership;

vii. Government retains the primary role and responsibility for ensuring the survival, livelihood and dignity of their citizens;

viii. Human security must be implemented with full respect for the purposes and principles enshrined in the Charter of the United Nations.

\section{UN Trust Fund for Human Security (UNTFHS)}

UNTFHS finance programs that translate the human security approach into practical actions and provide concrete and sustainable benefits to vulnerable people and communities threatened in their survival, livelihood and dignity.

UNTFHS finances activities carried out by UN organizations to demonstrate the added value of the human security approach and extend its usage and awareness both within and outside of the United Nations System.

\section{The 2030 Agenda for Sustainable Development}

The 2030 Agenda and its 17 Sustainable Development Goals (SDGs) is universal, transformative and right-based. It is an ambitious plan of action for countries, UN Systems, and all other actors. The agenda is the most comprehensive blueprint for eliminating extreme poverty, reducing inequality, and protecting the planet.

The 2030 Agenda contain the following core principles, namely: universality; leaving no one behind; interconnectedness and indivisibility; inclusiveness; and multi-stakeholders' partnerships.17 SDGs are not a summary of the Agenda, but rather focus areas necessary to achieve sustainable development. The 17 goals should be seen as indispensable pieces in a big and complex puzzle. The SDGs help translate the core values and principles underlying the 2030 Agenda into concrete and measurable results. 


\section{The New York Declaration for Refugees and Migrants}

On September 19 of 2016 the UNGA adopted the New York Declaration for Refugees and Migrants. It has paved the way for the adoption of two new global compact in 2018: a global compact on refugees and a global compact for safe, orderly and regular migration. The New York Declaration sets out the key elements of a Comprehensive Refugee Response Framework (CRRF) and the global compact on refugees. It also provides for the negotiation of a global, compact for safe, orderly and regular migration. The tow processes leading to the two global compacts are to be "separate, distinct and independent".

\section{The Sendai Framework for Disaster Risk Reduction}

The Sendai Framework for Disaster Risk Reduction 2015-2030 (Sendai Framework) provide Member States with concrete actions to protect development gains from the risk of disaster. It was endorsed by the UN General Assembly following the 2015 Third UN World Conference on Disaster Risk Reduction (WCDRR), and advocates for: the substantial reduction of disaster risk and losses in live, livelihoods and health and in the economic, physical, social cultural and environmental assets of persons, businesses, communities and countries.

\section{The Sustaining Peace Agenda}

The key messages of the UN Sustaining Peace Agenda are: preventing conflict and achieving lasting peace as enshrined in the UN Charter is a fundamental responsibility of the UN's Member States; The UN System's agencies, funds and programmes and Secretariat can play a catalytic role in sustaining peace but they need greater political, financial and operational support from Member States; Member States should support the UN to deliver the sustaining peace agenda in four (4) critical areas; above all, member countries must take the necessary diplomatic action to stop crises from escalating, bring parties back from the brink of violence and set them on the path to peace.

\section{Conclusion}

The developing concepts of LTSOSA, Space Security and Human Security are closely correlated which are emphasized to protecting and empowering people, for development, and dedicated both for Present and Future Generations. The achievement in space science and technology and its applications in the framework of LTSOSA and Space Security are potentially be contributed to the achievement of Human Security's Objectives. The Legal and Regulatory Framework of LTSOSA, Space Security and Human Security, both in the forms of hard laws, soft laws and other draft instruments are relevant and complementary to be used as guidance and reference to the achievement of Human Security's Objectives.

Author Contributions: Conceptualization, I.S.; Methodology, I.S.; Data Collection, I.S.; Formal Analysis, I.S.; Writing—Original Draft Preparation, I.S.; Writing - Review And Editing, I.S.; All authors have read and agreed to the published the final version of the manuscript.

Institutional Review Board Statement: Ethical review and approval were waived for this study, due to that the research does not deal with vulnerable groups or sensitive issues.

Data Availability Statement: The data presented in this study are available on request from the corresponding author. The data are not publicly available due to privacy.

Conflicts of Interest: The authors declare no conflict of interest.

\section{References}

Akhir, R., Miraza, B. H., Matondang, R., \& Djakapermana, R. D. (2016). Policy Space Utilization in Developing Area Medan-BinjaiDeli Serdang (Mebidang) Indonesia. International Journal of Regional Development, 3(1), 1-1.

Bejarano, S., Pardede, S., Campbell, S. J., Hoey, A. S., \& Ferse, S. C. (2019). Herbivorous fish rise as a destructive fishing practice falls in an Indonesian marine national park. Ecological Applications, 29(8), 1981.

Permatasari, Y. (2019). The Urgency of Guidelines for the Long-term Sustainability of Outer Space Activities for Indonesia. Global Strategis, 13(2), 63-74.

Budisulistiorini, S. H., Riva, M., Williams, M., Miyakawa, T., Chen, J., Itoh, M., ... \& Kuwata, M. (2018). Dominant contribution of oxygenated organic aerosol to haze particles from real-time observation in Singapore during an Indonesian wildfire event in 2015. Atmospheric Chemistry and Physics, 18(22), 16481-16498.

Hutagalung, J. M., Tobing, C. I., Debastri, J., \& Amanda, R. T. (2020, February). Space debris as environmental threat and the requirement of Indonesia's prevention regulation. In IOP Conference Series: Earth and Environmental Science (Vol. 456, No. 1, p. 012081). IOP Publishing.

Joan Liaschenko, R. N. (1997). Ethics and the geography of the nurse-patient relationship: Spatial vulnerabilities and gendered space. Research and Theory for Nursing Practice, 11(1), 45.

Lim, M. (2002). Cyber-civic space in Indonesia: From panopticon to pandemonium?. International development planning review, 24(4), 383-401.

Marandola, E., \& Hogan, D. J. (2006). Vulnerabilities and risks in population and environment studies. Population and Environment, 28(2), 83-112.

Matsuda, T. (2020). Explaining Japan's post-Cold War security policy trajectory: maritime realism. Australian Journal of International Affairs, 74(6), 687-703. 
Muawanah, U., Yusuf, G., Adrianto, L., Kalther, J., Pomeroy, R., Abdullah, H., \& Ruchimat, T. (2018). Review of national laws and regulation in Indonesia in relation to an ecosystem approach to fisheries management. Marine Policy, 91, 150-160.

Nastiti, F. N., \& Giyarsih, S. R. (2019). Green Open Space in Urban Areas: A Case in the Government Office of Boyolali, Indonesia. Regional Science Inquiry, 11(1), 19-28.

Nasution, A. D., \& Zahrah, W. (2017). Exploring Ideas in Formulating Urban Design Guidelines for Public Open Space in Sumatra Utara, Indonesia. Environment-Behaviour Proceedings Journal, 2(5), 439-447.

Siregar, J. P. (2014). Assessment of public space quality using good public space index (case study of Merjosari sub district, Municipality of Malang, Indonesia). Procedia-Social and Behavioral Sciences, 135, 10-17.

Yan, Y. (2019). Maintaining Long-Term Sustainability of Outer Space Activities: Creation of Regulatory Framework to Guide the Asia-Pacific Space Cooperation Organization and Selected Legal Issues. Space Policy, 47, 51-62.

Publisher's Note: SSBFNET stays neutral with regard to jurisdictional claims in published maps and institutional affiliations.

\section{(a) (1)}

(C) 2022 by the authors. Licensee SSBFNET, Istanbul, Turkey. This article is an open access article distributed under the terms and conditions of the Creative Commons Attribution (CC BY) license (http://creativecommons.org/licenses/by/4.0/).

International Journal of Research in Business and Social Science (2147-4478) by SSBFNET is licensed under a Creative Commons Attribution 4.0 International License. 